\title{
電力系統における電圧安定度の分類とその解析
}

\begin{tabular}{|c|c|c|c|c|}
\hline 正 員 & 餘利野 & 直 & 人 & (広島 \\
\hline 准 員 & 増 田 & 吉 & 彦 & (広 \\
\hline 員 & 佐々木 & 博 & 司 & (広 \\
\hline 員 & 西 亀 & 和 & 弘 & (広 \\
\hline 員 & 田 & 康 & 男 & \\
\hline 員 & 北 & & 稔 & to \\
\hline 会員 & 大 下 & & 哲 & （中国而 \\
\hline
\end{tabular}

\section{On Classification and Analysis of Voltage Stabilities in Power Systems}

Naoto Yorino, Member, Yoshihiko Masuda, Associate, Hiroshi Sasaki, Member, Kazuhiro Nishikame, Member (Hiroshima University), Yasuo Tamura, Member (Waseda University), Minoru Kitagawa, Member, Akira Ohshimo, Non-member (Chugoku Electric Power)

Voltage stability problem has long been studied by many researchers mainly by means of two approaches. One is static approach where voltage stability is considered as a load flow problem, while the other is dynamic approach in which it is dealt with as a stability problem in dynamic systems. However, these separate approaches have not clarified sufficiently the whole aspect of voltage problem up to now ; in fact, there are no proper criteria to determine which approach is suited to analyze voltage stability. Thus, a basic study seems to be needed under such situation.

This paper investigates voltage stability problem from the viewpoint of mechanism causing voltage instability. Various dynamic factors which affect voltages are studied as much as possible. In the first place, possible voltage instability patterns are classified based on singular perturbation theory. That is, four categories of instabilities are defined mathematically. Secondly, a method of stability assessment for each instability is presented. It is clarified that the determinant of the load flow Jacobian is an effective index to approximately assess two types of the instabilities. On the other hand, the remaining instabilities require eigenvalue analyses or direct nonlinear analyses. The validity of these results is verified through numerical simulations and eigenvalue analyses, in which dynamic characteristics of generating units, loads and tap-changing transformers are taken into account.

キーワード：電力系統の電圧安定度, 電圧崩壊, 不安定の分類, 特異捸動, 電圧低め解, 潮流ヤコビアン

\section{1.まえがき}

近年, 電源の遠隔化, 送電線の長距離化, 重潮流化 により,諸外国のみならす我が国においても，電圧安 定度問題への関心が急速に高まりつつある。電圧安定 度問題核来より様々な観点から研究が行われ，潮流 を主体とした静的な研究と系統や負荷の動的特性まで
も考慮した動的研究に大別される。前者については， $d Q / d V や d E / d V$ 理論などの潮流感度解析(1)(2) から,

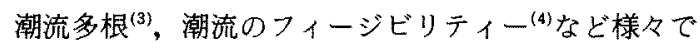
あるが，そのほとんどが定電力特性を仮定した潮流方 程式の解析に基づくものである。一方, 後者について は, 総括的な長尾氏の研究(5)をはじめ, 負荷として誘 導機特性を取扱ったもの ${ }^{(6)}$, 変圧器タップの線形化解 
析 ${ }^{(7)}$ 抢よび非線形解析( ${ }^{(8)}$ ，その他 ${ }^{(9)}$ ，幾つかの與味深 い研究がある。また，これら電圧問題を統一的見地か ら整理する試み(10)なども，一方で行われている。し かしながら，現在においても電圧問題の全貌を把挃す るに至っておらず, 本問題が静的問題, あるいは動的 問題であるのかなどの議論が後をたたないのが現状で ある。特に, 一連の静的研究と動的研究とのかかわり 合いについては, Venikov ${ }^{(11)}$, Thomas ${ }^{(12) ら に よ っ て ~}$ 定性的に簡略な考察がなされたに過ざず，ほとんど研 究が行われていない。例六ば, 我が国の電压事故（昭 和 62 年) では, リレーのトリップまでのしばらくの 間，潮流が低め電圧解側（潮流多根）にあったこと が, 後の解析で明らかにされているが,これらも動的 観点から静的な潮流問題を考察しなければならない一 つの例と考えられる。

そこで, 本論文では, 電圧問題を広く動的問題とし てとらえ，そのなかで潮流問題を取扱うことによっ て，上記の問題に一つの指針を与えることを目的とす る。まず，電圧問題が比較的緩慢な現象であることに 留意し特異提動理論 ${ }^{(13)}$ を用いて, 可能性のある不安 定性のメカニズムを分類する。そして簡単な3目線系 の例題を用い, 発電機, コントローラ, 非線形負荷, 変圧器タップなどの動的特性を忠実に模擬した動的シ ミュレーションと線形化モデルの固有值解析からこれ を例証する。この中では, 特に電圧問題のシミュレー

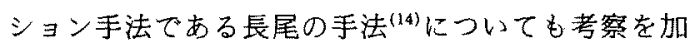
える。そして,こ机らの検討に基づき, 動的研究と静 的研究の関係に留意した定式化を行い，更にこれを用 いて, 上記で分類を行った各不安定性の判別法を明確 にする。なお，このとき，潮流多根問題についても動 的観点加考察を行う。

\section{2. 特異摂動理論の観点からみた電圧現象}

〈2・1〉特異摄動理論の導入包活的な動的視点 に立って電圧問題を考えるためには，全系にわたる動 的要因を可能な限り考慮しつつ, 統一的な理論体系に 基ついて問題を取扱うことが重要と考えられる。そこ でここでは電力系統のレスポンスに着目し，特異摄 動理諭(13)を用いて，図 1 に沿って問題を整理するこ とを提案する。周知の上うに電力系統の構成要因のう ち, 変圧器夕ップや火力 LFCなどは分单位の遅い応 動であり，発電機やAVR，ガバナなどの制御系は秒 単位の速い応動を示す。従って図 1 では, 電力系統の 状態変数を遅い変数 $x_{5}$ と速い変数 $x_{F}$ に分離してい る。また，時々刻々と変化する負荷をLoadで表現 し，これに追従して行われる制御（例えば，ELDな

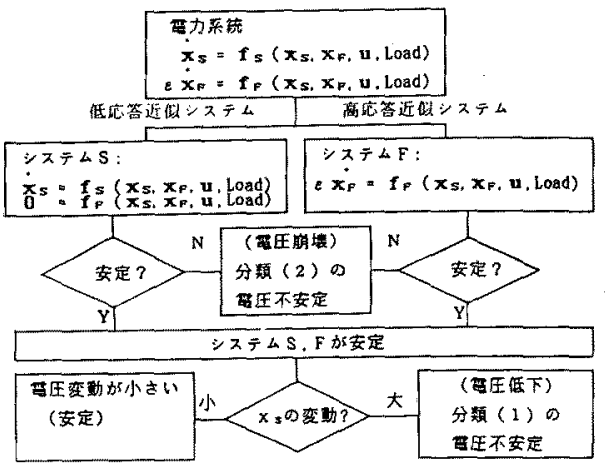

図 1 電圧不安定現象の分類

Fig. 1. Classification of voltage instabilities.

どの発電機の指令值変更，あるいは人為的な調相設備 の制御)をuで表現している。

なお，図1の二つの近似システム $S$ と $F$ は, 特異 摄動理論による零次近似システム吕)に相当するもの である。この場合，特異摄動理論を採用することの利 点法，問題の簡略化にあたって理論的に両近似システ ムの誤差の評価が可能な点, および誤差が許容できな い場合は, 更に高次の近似システムが構成可能な点に ある。

〈2・2〉電圧不安定の分類図1に扔いて発生し 得る不安定性を考える。まず, 系の平衡点は $0=f_{s}, 0=$ $f_{F}$ の根 $\left(x_{s 0}, x_{F 0}\right)$ であり，これは負荷 Load おょび 制御 $u$ に依存して時々刻々と変化している。このと き, システム $S$ は上記平衡点 $x_{s 0}$ に追従する緩慢な 系の動き $x_{s}$ を記述し, これが不安定である場合, $x_{s}$ は $x_{50}$ への回復力を失い, 徐々に $x_{50}$ から遠ざかるこ とになる。一般の非線形システム論加ら言光ば，この 不安定性流 $x_{s}$ が $x_{S 0}$ に追従し切れずに， $x_{s}$ の安定領 域（ $x_{50}$ の周りに存在し $x_{s}$ が回復力を有するアトラ クタと呼ばれる領域）から逸脱した場合に発生し得 る。さて,この $x_{s}$ の動きに伴う各時間断面で, $x_{s}$ を $0=f_{F}$ に代入した根 $x_{F S}$ は， $x_{F}$ の遅い成分である。す なわち，この $\left(x_{s}, x_{\text {Fs }}\right)$ がシステム $F$ の平衡点とな る。システム $F は こ の x_{F S}$ の周りで $x_{F}$ の速い動きを 記述し，これが不安定な場合も，系の安定運用は不可 能である。以上は，系が平衡点に対して，回復力を失 うことによる不安定であるが, 実際の電力系統では, 系が不安定に至らず安定領域内にあっても負荷の時間 的変化に起因して, 電圧が時間と共に低下していくよ うな状浣が発生し得る。これより実系統で電圧低下が 時間と共に拡大し，ついにリレートリップをまねく状 
況は，実際に系が不安定に至っている場合と安定領域 内で電圧低下が発生している場合の二種類が考えられ るが，一般に負荷とタップの変化が同程度の速度であ るので, 現象面だけで両者を区别するのは困難と考え られる。従って，解析にあたってはこれらを厳密に区 別しておく必要がある。以上をまとめると，時間的に 電圧が低下していく状況として，以下が想定される。

分類 (1) 負荷変化に対する安定領域内での電吉 低下

$$
\begin{aligned}
& \text { 分類(2) システム自体の不安定（電生崩壊） } \\
& (2-1) \quad \text { システム } S \text { の不安定 } \\
& (2-2) \quad \text { システム } F \text { の不安定 }
\end{aligned}
$$

\section{3. シミュレーションによる不安定現象の考察}

ここでは，シミェレーションを主体として，前章の 特異虂動的アプローチ（図1）の妥当性を示し，更 に電圧現象の詳細な考察を行う。電圧安定度に関与す る要因をできるだけ詳細に把握するために，例題系統 としては簡素な図 203 母線系統を用いる。この系統 は一つの発電機と二つの負荷からなり, 両負荷母線に は負荷時タップ切換え変圧器が接続されている。

〈3・1〉 電力系統モデル 電力系統は, 変圧器夕 ップの離散変数と発電機などの連続変数の混在するシ ステムである。詳細シミュレーションにおいては,こ

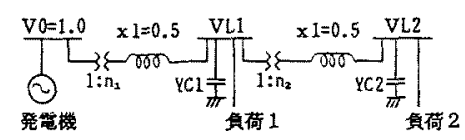

図 2 例題系統

Fig. 2. An example system.

表 1 系統変数の分類 $\left[\delta, \omega, \omega_{0}\right.$ 老除いて $\left.(\mathrm{pu})\right]$

\begin{tabular}{|c|c|c|c|c|}
\hline$x_{8}$ & & $\begin{array}{l}\text { 発電機内部位相角 }(\mathrm{rad}) \\
\text { 㡅压器タップ比 }(i=1,2)\end{array}$ & & \multirow{2}{*}{ 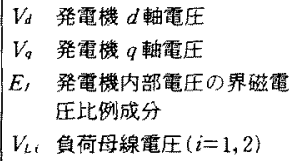 } \\
\hline \multirow[t]{2}{*}{$I_{F}$} & \multirow{2}{*}{\multicolumn{2}{|c|}{ 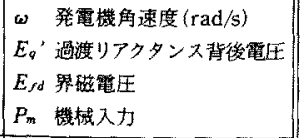 }} & & \\
\hline & & & & \multirow{3}{*}{ 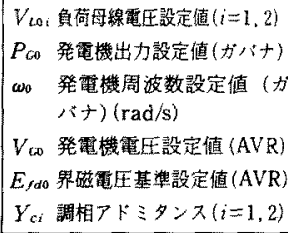 } \\
\hline$V$ & & $\begin{array}{l}i \text { 線電圧実部 }(i=1 \\
i \text { 線電压歔部 }(i=1\end{array}$ & u & \\
\hline \multirow[t]{2}{*}{$y$} & & 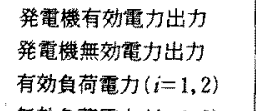 & & \\
\hline & $Q_{21}$ & 2) & & $\begin{array}{l}P_{0 i} \text { 基準有効負荷 }(i=1,2) \\
Q_{0 i} \text { 基染無効負荷 }(i=1,2)\end{array}$ \\
\hline
\end{tabular}

Table 1. Classification of state variables in pu (except $\left.\delta, \omega, \omega_{0}\right)$.
れらの特性を忠実に模擬するものとする。一方，後の 節で現象解析を行う際は, 離散変数は連続化し, 固有 值解析を適用する。また，後の解析の都合上，系全体 が既に連続化されているものとし，電力系統を次式の 一般形式で表現する。

$$
\begin{aligned}
& \dot{x}_{s}=g_{s}\left(X_{F}, V, u\right) \cdots \cdots \ldots \ldots \ldots \ldots . \cdots \\
& \dot{x}_{F}=g_{F}\left(x_{s}, x_{F}, V, y, x, u, \text { Load }\right) \\
& 0=h_{F}\left(x_{s}, x_{F}, V, y, z, u, \text { Load }\right) \\
& y=h_{N}\left(x_{s}, x_{F}, V, u\right) \cdots \cdots \cdots \cdots \cdots
\end{aligned}
$$

ここで（1）および(2)式を合せて全系の微分方程式 を表現している。また（3）式㹥発電機と負荷特性を 表す代数方程式，(4)式は潮流方程式である。ここで $V$ は母線電圧, $y$ は潮流計算の指定值, $z$ は発電機 と鿓荷に関連した徒属変数, $u$ は指令入力, Loadは 負荷を表し，各々はベクトルである。例題系統におけ るこれらの変数の詳細は，表1に示した。以下，同表 に沿って (1)〜 (4) 式の説明を行う。なお, 図 1 の最 上段の電力系統モデルは，(3) と(4)式の代数方程式 を用いて $V, y, z$ を消去したものに相当している。

(1) 変圧器ユニット $\langle 3 \cdot 2\rangle,\langle 3 \cdot 3\rangle,\langle 3 \cdot 5\rangle$ 節 のシミュレーションでは離散モデルを, 〈3・4〉節の固 有值解析では連続化モデルを用いる。図 3 にこの特性 を示す。まず，離散モデルについて説明する。負荷 $i$ の母線電圧を $V_{L i}$, 基準電圧（指令値）を $V_{L 0 i}=$ $1.0 \mathrm{pu}$, 変圧器のタップ比を $n_{i}$ とするこのとき, 電圧偏差 $\Delta V_{i}\left(=V_{L i}-V_{L 0 i}\right)$ が設定された許容値 $\left(\Delta V_{i}=0.01 \mathrm{pu}\right)$ を超し, その状態坫一定期間 $T_{n}=$ 1.5 (分) 継続すると, $\Delta n_{i}=0.01$ 単位でタップを動 作させる。タップの上下限は $n_{\text {max }}=1.25, n_{\min }=0.85$ で与える。一方, 連続化モデルにおいては, 文献 (7) に従って, 上記特性を以下の一次遅れ系で近似する。

$$
\dot{n}_{i}=-\frac{1}{T n_{i}^{\prime}}\left(V_{L i}-V_{L 0 i}\right)
$$

ただし，

$$
T n_{i}^{\prime}=T n_{i} \cdot V_{L 0} i / \Delta n
$$

これは, 本来 $T_{n}$ 時刻後に1段 $(\Delta n)$ 変化する変圧器 タップを連続的に変化させ， $T_{n}$ 時刻後に $0.635 \Delta n$ 変 化するよう近似したことに相当する。タップの動作時

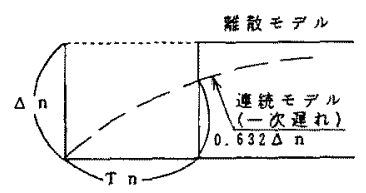

図 3 変圧器タップ制御特性

Fig. 3. Characteristics of tap-changers. 
間は分単位であるので, 表 1 では $n_{i}$ を遅い変数 $x_{s}$ と して分類している。上記の変圧器タップ特性は，（1） 式の一部として表現している。

（2）発電機ユニット 発電機としては, 文献 （15）より界磁鎖交磁束変化および突極性を考慮した三 次元モデルを採用した。また，AVR，ガバナは飽和 のない一次遅れ系として模擬した。飽和㤝, 電圧安定 度を考光る場合, 極めて重要な要因と考えているが, ここでは現象の分類を簡絜に行う目的で，これを無視 する。また同様の理由で LFCも省略する。すなお ち, 発電機ユニットとして, 表 1 の五次元の状態変数 $\left(\delta, \omega, E_{q}^{\prime}, E_{f d}, P_{m}\right)$ を用いた微分方程式を採用した。

一般に発電機は，低レスポンスな全系の憒性中心の周 りで秒単位の応動を示すことが知られている ${ }^{(16)}$ 。例 題系統は一機系でありるが系統の慣性中心に相当す るので,ここでは表 1 のように $\delta$ を遅い変数 $x_{s}$ ，そ の他を速い変数 $x_{F}$ として分類した。以上, 変圧器お よび発電機ニニットより，(1)および (2)式の微分方 程式が構成される。一方, 母線と発電機内部を接続す る $d q$ 変換などの一連の代数方程式は，(3) 式に含ま れている。な扔シシュレーションに使用する発電機 ユニットの定数は表 2 に示した。

（3）負荷 負荷 1 おうさび 2 として電圧, 周波数 特性を模擬した以下の静的モデルを用いる。

$$
\begin{aligned}
& P_{L i}=P_{0 i} V_{L i}^{0.5} f^{1.2} \\
& Q_{L i}=Q_{0 i} V_{L i}^{2.0} f^{0.1}
\end{aligned}
$$

ここで， $f=\omega / 2 \pi$, 上式に含まれる変数の説明おる び分類については，表１を参照されたい。本負荷表現 では同表に示したように， $P_{0 i}, Q_{0 i}$ がべクトル Load を構成するが，後のシミュレーションでは，この Load を外部からの入力として変化させている。な

表 2 発電機ユニットの定数

Table 2. Constants of generating unit.

\begin{tabular}{c|c|c|c|c|c|c|c|c}
\hline \multicolumn{3}{c|}{} & \multicolumn{3}{c|}{ AVR } & \multicolumn{2}{|c|}{ ガパ+ } \\
\hline $\begin{array}{c}\text { 電機定数 } \\
(s)\end{array}$ & $\begin{array}{c}T_{d^{\prime}} \\
(\mathrm{s})\end{array}$ & $\begin{array}{c}x_{d^{\prime}} \\
(\mathrm{pu})\end{array}$ & $\begin{array}{c}x_{d} \\
(\mathrm{pu})\end{array}$ & $\begin{array}{c}x_{q} \\
(\mathrm{pu})\end{array}$ & $K_{A}$ & $\begin{array}{c}T_{A} \\
(\mathrm{~s})\end{array}$ & $K_{c}$ & $\begin{array}{c}T_{c} \\
(\mathrm{~s})\end{array}$ \\
\hline 22.0 & 3.50 & 0.10 & 0.34 & 0.30 & 50.0 & 0.50 & 40.0 & 0.50 \\
\hline
\end{tabular}

お，(6)式は(3)式に含まれる。

(4) 系統 系統は全母線について, $P, Q$ 指定 に相当する直角座標系の潮流方程式を用い，(4)式と して表現する。これにより発電機の内部状態と負荷端 の状態が各母線の $P Q$ 值を介して関係し合う。

以上より，例題系統は(1)〜 (4)式で表現された。 ここで各式の次元は，(1) 式が 3 次元 $\left(=\operatorname{dim} x_{s}\right)$, (2) 式が 4 次元 $\left(=\operatorname{dim} x_{F}\right),(3)$ 式が11次元 $(=$ $\operatorname{dim}(y+z)\},(4)$ 式が 6 次元 (= $=\operatorname{dim} V=\operatorname{dim} y)$ である。

$$
\text { 〈3・2〉シミュレーション方法（6)式の }
$$
Load $=\left[P_{01}, Q_{01}, P_{02}, Q_{02}\right]$ を変化させ, 図 4 および表 3 に示す 3 ケースの負荷増加パターンを設定した。ケ 一ス 1 は軽負荷かつ負荷の增加速度も幄い場合, ケー ス 2 は中程度の負荷から重負荷に変化する場合,ケー 又3汒更に重負荷に変化する場合である。シミュレー ション方法については, 上記の各ケースに対して, ま ず $t=0$ に扔いて，(1)〜(4)式で左辺を零と㯰いた 平衡状態 $\left(x_{s 0}, x_{F 0}\right)$ ：ただし変圧器タップについては 不感帯内にある状態を求めた。そして, これを初期値 として, 発電機ユニットに対して 0.02 秒間隔のルン ゲクッタ法を適用し, 各刻み時間ごとに変圧器タップ の離散動作を考慮して解を求めた。各ステップにおい ては，まず表 3 の值に従って，上記 Load 抢よび を入力し, 状態 $\left(x_{s}, x_{F}\right)$ の值を用いて，(3)，(4) 式から $V, y, z$ を求め, これらの值より次の状態 $\left(x_{s}\right.$, $x_{F}$ ）を計算している。

\section{〈3・3〉詳細シミュレーションによる電圧現象}

本シミュレーションの結果を図 $5(\mathrm{a})$ および(b)に 示す。図 5 (a) 注, 変圧器タップ比 $n_{1}, n_{2}$ の変化を示 し, 図 $5(\mathrm{~b})$ はこのときの負荷母線電压 $V_{t 1}, V_{x 2} て$

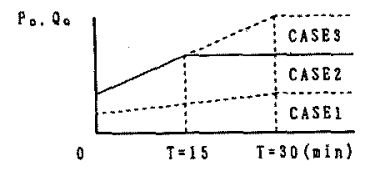

図 4 真荷の増加バターン

Fig. 4. Load increasing patterns.

\begin{tabular}{|c|c|c|c|c|c|c|c|c|c|c|c|c|c|c|c|}
\hline & \multicolumn{4}{|c|}{ 負荷 1 (pu) } & \multicolumn{4}{|c|}{ 負荷 2 （pu） } & \multicolumn{7}{|c|}{ 設 定 值 } \\
\hline & $P_{\min }$ & $P_{\max }$ & $\overline{Q_{\mathrm{mln}}}$ & $Q_{\max }$ & $P_{\min }$ & $P_{\text {пих }}$ & $Q_{\mathrm{mnn}}$ & $Q_{\max }$ & $V_{\text {toi }}$ & $P_{000}$ & $\omega_{0}$ & $V_{c o}$ & $E_{f d 0}$ & $\overline{Y_{c \mathrm{I}}}$ & $Y_{c 2}$ \\
\hline CASE 1 & 0.10 & 0.40 & 0.06 & 0.24 & 0.10 & 0.20 & 0.05 & 0.10 & 1.0 & 0.20 & $2 \pi \cdot 60$ & 1.0 & 1.007 & 0.06 & 0.06 \\
\hline CASE 2 & 0.30 & 0.60 & 0.18 & 0.36 & 0.30 & 0.40 & 0.15 & 0.20 & 1.0 & 0.60 & $2 \pi * 60$ & 1.0 & 1.058 & 0.26 & 0.20 \\
\hline CASE 3 & 0.30 & 0.78 & 0.18 & 0.47 & 0.30 & 0.50 & 0.15 & 0.25 & 1.0 & 0.60 & $2 \pi \cdot 60$ & 1.0 & 1.058 & 0.26 & 0.20 \\
\hline
\end{tabular}

表 3 シミュレーションケース

Table 3. Simulation cases. 


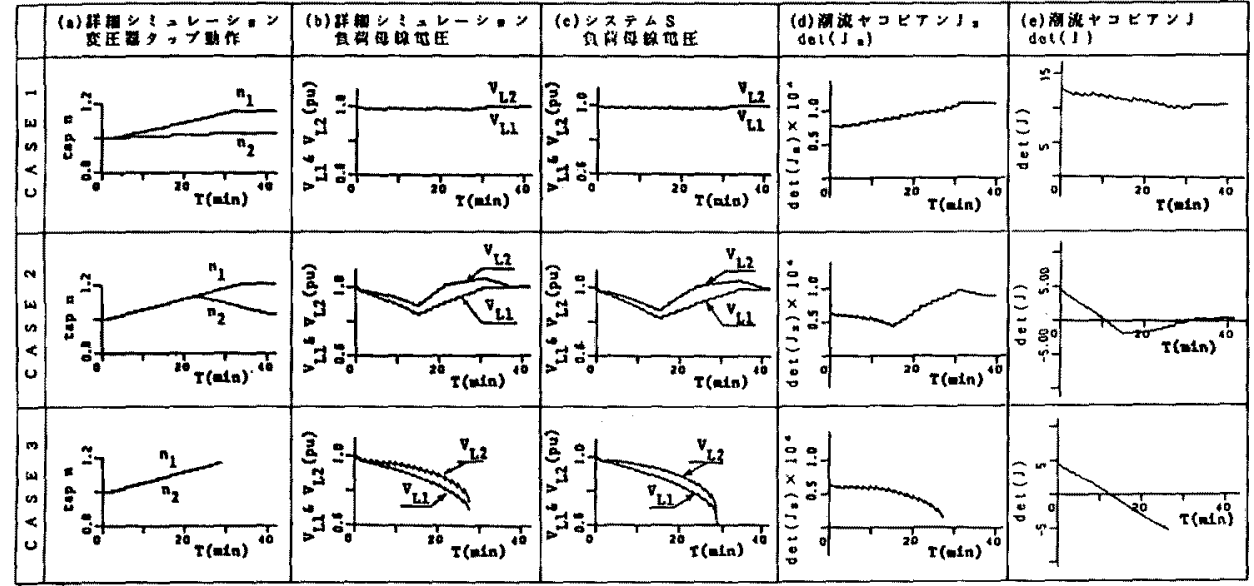

図 5 シミュレーション結果

Fig. 5. Simulation results.

ある。

（1）不安定性の分類 まず，軖負荷なケース 1 では, 制御が負荷変化に追従し，電圧はほほ規定值以 内に保たれている。これに対して，重負荷かつ負荷の 増加速度を速めたケース2では制御遅れが目立ち電瓜 低下が著しい。しかし, 負荷の增加が飽和した後も変 王器タップが制御を綍け, 最終的に電圧を $1.0 \mathrm{pu}$ 杘しており，数学的な意味でシステム自体は安定であ る。すなわち，これは分類 (1) の電圧低下に相当する と考えられる。次に，更に重急荷量なケース 3 に注目 する。本ケースでは，まず分類 (1)と考えられる電圧 低下に始まり，これに伴って細かい振動が発生し，更 に27 分以降この振動が発散していったためシミュレ ーションを打奶った。すなわち，この27分の直前に おいて，高応答なシステム $F$ の不安定に直面したも のと解秎され，これは分類 (2)，特に(2-2)の不安定 に相当する。この解釈が正しいことは，後の節の解析 を通して明らかになる。

(2) 電圧低下と平衡点加らの変位 ケース 20 負荷変化は時刻 15 分で飽和するため平衡点 $\left(x_{s 0}\right.$, $x_{F 0}$ ）は，それ以降は定数である。従って，時刻 15 分 からタップが平衡点に達する時刻 40 分までの間のシ ステム状態 $x_{s}$ ，および $x_{s}$ に従属して変化する䉓圧 $V$ は，上記平衡点に収束するまでの過渡状態と解釈 でる。すなわち，これは，負荷が0〜15分にかけて急 激に変化したため, 平衡点 $x_{s 0}$ が急激に変化し, 変化 の漣い $x_{S}$ が $x_{50} に$ 収束できずにいる状態である。

このように,タース2の最大電圧低下 $0.3 \mathrm{pu}$ (時 刻 15 分)，は，極めて遅い状態変数を含む動的システ
ムの過渡現象としての意味をもつ。これは，今後の解 析上，特に留意すべき重要な点である。

\section{〈3・4〉固有値による近似システムの考察}

(1) 近似システムの構成 前章の図1で述べた 特異揸動理諭に基づけば，(1)〜(4)式の近似システ 厶 $S, F$ は，各々次式で与えられる。

$$
\begin{aligned}
& \text { システム } S \text { : } \\
& \dot{x}_{s}=g s\left(x_{F}, V, u\right) \\
& 0=g_{F}\left(x_{s}, x_{F}, V, y, z, u \text {, Load }\right) \\
& 0=h_{F}\left(x_{s}, x_{F}, V, y, z, u \text {, Load }\right) \\
& y=h_{N}\left(x_{s}, x_{F}, V, u\right) \\
& \text { システム } F \text { : } \\
& \dot{x}_{F}=g_{F}\left(x_{s}, x_{F}, V, y, z, u, \text { Load }\right) \\
& 0=h_{F}\left(x_{s}, x_{F}, V, y, z, u \text {, Load }\right) \\
& y=h_{N}\left(x_{s}, x_{F}, V, u\right)
\end{aligned}
$$

まず，固有值解析を適用するために，u占よび Load を固定して，（1）（4)式を平衡点 $\left(x_{s 0}, x_{F 0}\right)$ の周りで線形化する。更に，従属変数 $V, y, z$ を消去 すると，原システムの線形化システムが得られる。

$$
\left[\begin{array}{c}
\Delta \dot{x}_{S} \\
\Delta \dot{x}_{F}
\end{array}\right]=\left[\begin{array}{ll}
A_{S S} & A_{S F} \\
A_{F S} & A_{F F}
\end{array}\right]\left[\begin{array}{l}
\Delta x_{S} \\
\Delta x_{F}
\end{array}\right]
$$

また，同様に(7)および( 8 )式の線形化を行えば， 各々の近似線形化システムは，(9)式の行列の要素を 用いて次式の上うに表現される。

$$
\Delta \dot{x}_{s}=A_{s} \Delta x_{s}
$$

ただし，

$$
\left.\begin{array}{l}
A_{S}=A_{S S}-A_{S F} A_{F F}^{-1} A_{F S} \\
\Delta \dot{x}_{F}=A_{F F} \Delta x_{F}
\end{array}\right\}
$$


（2）固有值による近似システムの諾差評洒 ケース1と2に扔ける時刻 40 分の状態（システム 全体の平衡状態) の固有値を調へる。表 4 の左橍に (9)式で示されるシステム全体の詳細固有值を, 䋓対 値の順（レスポンスの遅い順）に示す。また表 4 右欗 に(10)抢よび(11)式の近似システムの固有値を示す。 まず左攔に注目すると，ケース $1 ， 2$ ともに遅い固有 值 $\lambda 1 \sim \lambda 3$ と速い固有值 $\lambda 4 \sim \lambda 7$ の絶対值の比は, 概 略 $10^{3}$ 程度であり，己林近似システムの誤差は， 理論的に $10^{-3}$ のオーダと見積られる。実際に表 4 左 右の欄を比較すると, 両ヶースについて左欄固有值と 右欄の近似固有值は, $10^{-3}$ オーダで完全に一致して いることが確認される。これより，図10特異聣動法 が良好に機能することが示された。

（3）負荷状態とシステム全体の平衡状態の関係 ここでは $\left(x_{s}, x_{F}\right)$ が平衡点の $\left(x_{F 0}, x_{s 0}\right)$ に収束 した状態，すなわちケース 1 と 2 の時刻 40 分の状態 で固有値解析を行う。ケース 3 では, 同時刻において 既に電圧崩壊が発生しているため, 考察対象から除外 し, 表 4 においてケース 1 と 2 の固有值変化に注目す る。虚軸方向人の変化法，特に $\lambda_{s 2}$ と $\lambda_{F 3}$ に見ら

表 4 システム全体の固有値

Table 4. Eigenvalues of the whole system.

\begin{tabular}{|c|c|c|c|c|c|c|c|}
\hline \multicolumn{4}{|c|}{ CASE 1} & \multicolumn{4}{|c|}{ CASE 2} \\
\hline \multicolumn{2}{|r|}{ 全システム } & \multicolumn{2}{|c|}{ システム $F 、 S$} & \multicolumn{2}{|r|}{ 全システム } & \multicolumn{2}{|c|}{ シスデム $F, S$} \\
\hline d] & 0.0 & $A S 1$ & 0.0 & $\lambda 1$ & 0.0 & $\lambda S t$ & 0.0 \\
\hline 12 & -0.000096 & $\lambda S$ & -0.009096 & 12 & -0.000076 & $\lambda S 2$ & -0.000076 \\
\hline 13 & -0.000123 & $\lambda S 3$ & -0.000123 & 13 & -0.000128 & $\lambda S 3$ & -0.000128 \\
\hline$\lambda 4$ & $-1.000+j 0.905$ & $A F$ & $-1.000+j 0.905$ & 14 & $-1.000+j 0.905$ & $\lambda F 1$ & $-1.000+j 0.905$ \\
\hline$\lambda 5$ & $-1.000-\mathrm{j} 0.905$ & $\lambda F$ & $-1.000--j 0.905$ & 15 & $-1.000-j 0.905$ & $\lambda F_{2}$ & $-1.000-j 0.905$ \\
\hline 16 & $-1.133+55.296$ & $\lambda F 3$ & $-1.133+j 5.296$ & $\lambda 6$ & $-1.085+j 5.674$ & $\lambda F 3$ & $-1.085+55.674$ \\
\hline 17 & $-1.133-j 5.296$ & $2 F 4$ & $-1.133-j 5.296$ & $\lambda 7$ & $-1.085-j 5.674$ & $\lambda F 4$ & $-1.085-j 5.674$ \\
\hline
\end{tabular}

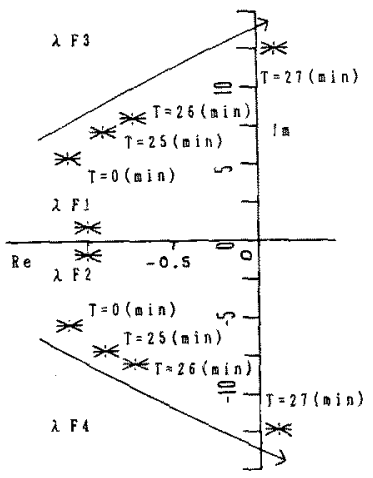

図 6 システムFの固有值の動き

Fig. 6. Behavior of the eigenvalues of system $F$.
れるが,この変化はそれほど大きなものではない。すな ち, 平衡点 $\left(x_{50}, x_{F 0}\right)$ の安定性に関しては,この場合, 重負荷の影響をあまり受けていないことがあかる。

(4) 負荷状態とシステムFの平衡状態の関係 ケース 3 について，システムFの平衡点 $\left(x_{s}, x_{F s}\right)$ の状態を調心る。このために各時刻の $x_{s}$ を用いて， $(7 \mathrm{~b}) \sim(7 \mathrm{~d})$ 式を满たす $x_{F}$ (すなわち平衡点 $\left.x_{F S}\right)$ を求め, 各時刻の $x_{F S}$ の周りで評任した(11)式の線 形化システムを考える。図 6 にこの $A_{F F}$ の固有值の 動きを示す。同図に見られるように， $\lambda_{F 3}$ と $\lambda_{F 4}$ は虚 軸に接近し, 時刻 27 分において, 二つの固有値の実 部は正になることが確認される。このことからケー ス 3 の電压崩壊は，システム $F$ の不安定によるもの と結論される。

以上の項目 (3)，(4)を併せて考察すれば，システ 公の真の平衡点 $\left(x_{S 0}, x_{F 0}\right)$ は，重鿓荷の影響をあま り受けないが， $x_{S}$ の動きが負荷の急増に追従せず電 圧が低下するに伴って，システム $F$ の平衡点 $x_{F S}$ が 不安定になる場合が起こり得ることがわかる。

\section{〈3.5〉 システム $S$ のシミュレーション（長尾の手} 法）長尾の手法 ${ }^{(14)}$ は, 電王安定度のシミュレーシ ヨン手法として提案されているもので, 発電機, 制御 系などを代数化し，これと潮流方程式执よび負荷特性 を連立させ $N-R$ 法により電圧解を求め，そのときの 条件によって変圧器タップを動作させる手法である。 これは，本論文の考えに基づけば，前述の(7)式に相 当するシステム $S$ のシミュレーション手法にほかな らないと解积できる。この長尾の手法を前述のケース 1〜3に適用した結果を図 5 (c)に示す。まずケー ス 3 の時刻 28 分以降に注目すると, 訮細シミュレー ションがシステムFの不安定に至った後も，長尾の 手法では電圧解を与えている。これは，前述のよう以 ジスム $S$ では，システム $F$ の安定性が暗仮仮定き れているためである。しかしながら，この点を除け ば，図 5(c)岵全ケースに対し図 5(b)の詳細シミュ レーション結果を良好に模擬している。以上の結果 は,図 1 の妥当性を示すと同時に, 長尾の手法とシステ ム $F$ の安定性評価（例えば固有値法など）の組合せで， 詳細な安定判別が可能であることを示している。

\section{4. 各分類の電圧安定条件と静的解析との 関連}

前章の結果に基づけば，分類（1）の電圧低下とし て， $x_{S}$ が負荷変化に追従しない場合が举げられ，こ のとさ更に，分類(2-2)の不安定に至る場合があるこ とが判明した。ここでは，これらの不安定性の条件を 
考察する。なお，分類(2-1) の不安定条件に関しては, $〈 3 ・ 3 〉$ 節 (2)の結果より詳細な非線形解析を必要とす ると思われるのでこここでは扱わない。ここでの解析 は現在広く行われている潮流解析を意識して，通常の 潮流計算ヤコビアン $J$ に注目する。 $J$ は，(4)式のヤ コビアン $J_{N}$ からスラック母線に相当する 2 行 2 列 (次式の*印) を取り除いた小行列として, 次式のよ うに記述される。

$$
J_{N}=\left[\frac{\partial h_{N}}{\partial V}\right]=\left[\begin{array}{ll}
* & * \\
* & J
\end{array}\right]
$$

〈4・1〉定式化および理論的考察 ジステムSO 各時間断面 $\left(x_{S}, x_{F S}\right)$ において，上記 $J_{N}$ に留意しな がら (8)式のシステム $F$ を線形化する。その際, 微 小負荷変化 $\Delta$ Loadに対して制御系の指令值を変更し ない $(\Delta u=0)$ ことを仮定し，yと $z$ を消去すれば次 式を得る。

$$
\begin{aligned}
{\left[\begin{array}{c}
\Delta \dot{x}_{F} \\
0
\end{array}\right]=} & {\left[\begin{array}{cc}
H_{F} & H_{V} \\
Y_{F} & J_{N}-Y_{V}
\end{array}\right]\left[\begin{array}{c}
\Delta x_{F} \\
\Delta V
\end{array}\right] } \\
& +\left[\begin{array}{c}
H_{L} \\
Y_{L}
\end{array}\right] \Delta \text { Load } \ldots . . .
\end{aligned}
$$

ここで特に $H_{F}$ は定数行列， $J_{N}$ は(12)式のヤコビア ンである。また， $H_{V}, H_{L}, Y_{F}, Y_{V}, Y_{L}$ は状態 $x_{S}$ に依 存する行列である。

（1）分類(1)の電圧低下 （13）式で $\Delta \dot{x}_{F}=0$ と 置き，更に右辺の $\Delta x_{F}$ を消去すると，次式を得る。

$$
\Delta V=-J_{s}^{-1} L_{s} \Delta \mathrm{Load}
$$
ただし

$$
\begin{aligned}
& J_{S}=J_{N}-K_{N}, K_{N}=Y_{V}+Y_{F} H_{F}^{-1} H_{v} \\
& L_{S}=Y_{L}-Y_{F} H_{F}^{-1} H_{L}
\end{aligned}
$$

上式はシステム $S$ の各時間断面で負荷増加と電圧低 下の程度を示す関係式である。(14)式より $\operatorname{det}\left(J_{s}\right)$ が 小さい場合, 負荷の増加に伴って単位時間に低下する 電圧が大きくなることが指摘できる。言い搮えれば， 変压器タップが一段変化するまでに(14)式の左辺の負 荷 $\Delta \operatorname{Load}$ が増加する際, その後のタップ一段の変化 で左辺の $\Delta V$ が補償できれば，分類(1)の電压低下 㹥発生しないことになる。通常のタップの応答特性 は, 変圧器ごとに一定であるので，上式より分類(1) の電压低下の評価基準として，以下が挙げられる。

$$
\operatorname{det}\left(J_{S}\right) \rightarrow 0
$$

前章までの検討て，分類（1）の電王低下は， $x_{s}$ (あ るいは制御 $u$ ）が追従しないために発生することを示 したが，上の議論に基づけば， $x_{s}$ (あるいは 影響は(15)式にも現れるはずである。これについて は, 次節のシミュレーションで検討する。さて,ここ

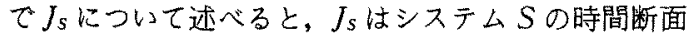
を求める際， $(7 \mathrm{~b}) \sim(7 \mathrm{~d})$ を連立して $N-R$ 法を用い て解く場合のヤコビアンに相当している。そして， (14)式より明らかなように， $J_{S}$ は (12) 式の $J_{N}$ を行列 $K_{N}$ で補正することにより求められる。なお， $K_{N}$ は2 ×2 の小行列を対角要素とするブロック対角行列とな り, 各ブロックは, 各発電機ユニットおよび負荷の特 性を表している。

（2）分類 (2-2)の不安定 (13) 式に拟 $\Delta \mathrm{Load}=0$ として $\Delta V$ を消去すると, 前述の(11) 式 に帰着する。このとき $A_{F F}$ は次式で与えられる。

$$
A_{F F}=H_{F}-H_{V}\left(J_{N}-Y_{V}\right)^{-1} Y_{F}
$$

システム $F$ の安定限界は $A_{F F}$ の固有值実部が雾のとき である。その際，固有值が零を通過するかあるい住軸 を通過するかにより，以下の二種類が考えられる。

(2-2S) 静的分岐: $\operatorname{det}\left(A_{F F}\right)=0$

(2-2 D) 動的分岐: $\operatorname{det}\left(A_{F F}\right) \neq 0$

ここで，上記のように静的分岐をシステム $F$ で扱う のは，澉密には愦りである。これは， $A_{F F}$ の固有值が 零に近づくとシステム $F$ が低レスポンスな様相を带 び，近似システムの愦差が拡大するためである。しか しながら，前節で解析を行ったように，一般にシステ ムSとFのレスポンスの比は極めて大きいと考えら れ, 更にシステムSが傩散変数から構成されるため, 本論文の取报いは十分妥当であると考えられる。な お，前述のケース 3 は，図 6 上り動的分岐の例で ある。

(3) $\operatorname{det}\left(J_{s}\right)$ による安定判別 (13)式の右辺第 1 項の行列を $D$ とすれば，以下の関係が成り立つ。

$$
\begin{aligned}
\operatorname{det}(D) & =\operatorname{det}\left(H_{F}\right) \operatorname{det}\left(J_{S}\right) \\
& =\operatorname{det}\left(J_{N}-Y_{V}\right) \operatorname{det}\left(A_{F F}\right)
\end{aligned}
$$

ここで, 前述のように $H_{F}$ は定数行列であり, $\operatorname{det}$ $\left(H_{F}\right) \neq 0$ は保証されている。これより $(15)$ 式の十分条 件として，(17)式の静的分䁌が挙げられることがかか る。すなわち，系統運用において $\operatorname{det}\left(J_{s}\right)$ を計算すれ 仿，分類 (1)の意味での電压低下に加え，分類(2-2 S)の静的分岐を監視することができる。ただし，分 類 (2-2D)の動的分䁌を監視するためには，AFF の固 有値計算が必要である。

（4）通常の潮流解析通常の潮流解析において は, 受電端電力一電圧特性曲線（ノーズカーブ）の先 端が安定限界として扱われている。これを数学的に誩 い搮えれば，評洒基準として次式を採用していること からになる。

$$
\operatorname{det}(J) \rightarrow 0
$$


以下，上式と(15)式の関係を示す。 $J_{s}$ は，(14)式よ り $J_{N}$ と $K_{N}$ よりなり, 更に $J_{N}$ は(12)式のようにJ を含むので，(21)式のようにJとそれ以外の部分 $K_{i}$ に分割できる。そして，(21)式より直ちに(22) 式が得 られる。

$$
\begin{aligned}
& J_{s}=\left[\begin{array}{ll}
0 & 0 \\
0 & J
\end{array}\right]-\left[\begin{array}{ll}
K_{11} & K_{12} \\
K_{21} & K_{22}
\end{array}\right] \ldots \ldots \ldots \ldots \ldots \ldots \ldots \\
& \operatorname{det}\left(J_{s}\right)=\operatorname{det}\left(K_{11}\right) \operatorname{det}(J-K)
\end{aligned}
$$
ただし，

$$
K=K_{22}+K_{21} K_{11}^{-1} K_{12}
$$

通常, $\operatorname{det}\left(K_{11}\right) \neq 0$ であるので，(15)式と等価な判定

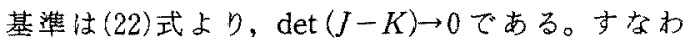

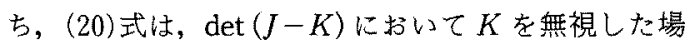
合の近似としての意味をもち, 上記 ( 3 )項で述べた電 生安定度を、近似的に謤価する手段であると解釈で きる。

\section{$\langle 4 \cdot 2\rangle$ 数 值 例}

(1) $\operatorname{det}\left(J_{s}\right)$ の振舞い 図 5(d)に前述のシミ ュレーションに招ける $\operatorname{det}\left(J_{s}\right)$ の振舞いを示す。これ は, 前節で考察を行ったように, 分類 (1) および (2-2 S)の意味で電圧安定度を表している。同図において， 特に分類 (2-2 D) の不安定に至るケース 3 に注目する と，この不安定に至る以前に $\operatorname{det}\left(J_{s}\right)$ の值も零に溸近 し, 分類 (1)の意味でも安定度が低下していることが わかる。

(2) $\operatorname{det}(J)$ の振舞い 図 $5(\mathrm{e})$ にdet $(J)$ の值 を示す。まずケース 2 に注目すると，時刻 10 分から 30 分に加けて符号が反転し，(20)式における臨界值 を通過している(ケース 3 も同様)。図 7 にケース 2 の時刻 0 分と 20 分の状況をノーズカーブ上に示した が，これに見られるように， $\operatorname{det}(J)$ の符号反転は， 従来運用不可能との䜑識が主流を占めていた電圧低力

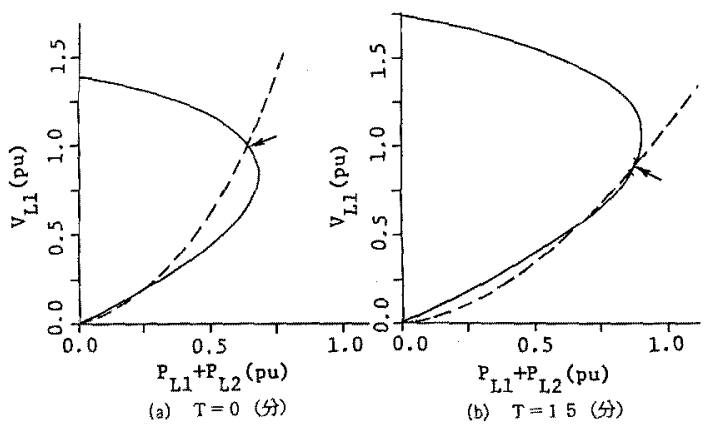

图 7 ケース 2 の運用状態

Fig. 7. Operating condition for case 2 .
解 (潮流多根) 側での運用に相当している。そして， このシミュレーション結果は,リレートリップなどが 発生しない限り，低め解での運用も可能な場合がある ことを示している。この例にも見られるように、いわ ゆる潮流計算のみによる厳密な安定判別は不可能であ る。しかしながら，この点に留意しておけば，(20)式 の $\operatorname{det}(J)$ は, 分類 (1) 极よU゙(2-2S)の意味で, 概略 的な電圧安定度を知るための有効な指標となり得る。 これは, 図 5(b)と(e)の概形がほほほ相似であること からも，納得できる。

\section{5.あとがき}

本論文では，簡略な 3 母線系統を例題として，詳細 に電圧不安定現象を考察した。ここで行った系統表 現, 定式化, 不安定性の份類, 安定判別法などについ ては，多機系統の場合に適用可能な一般性を有してい る。今後の検討としては, 本論文で考察対象外とした 低レスポンス近似システムの直接的な非線形解析，古 るいは本論文の理論を大規模系統に適用する際の計算 の効率化などが重要と考えられる。また，これまでの 電圧事故において，リレ一動作の前後の状態か，本論 文で述べた安定度の分類上，どの状態に属するかを知 ることは，今後の対策を考えるうえで極めて重要と考 えられる。

(平成元年 7 月 17 日受付)

\section{文献}

(1) V.A. Venikov, et al.: "УСТО ИЧнВОСТЬ НАГРУЗКИ" НЗВАКАД НАУК СССР, ОТН (ЗНЕРГЕТ И АВТСМАТН KA), No. 3, 121 (1961)

(2) B. M. Weedy \& B. R. Cox: "Voltage Stability of Radial Power Links", Proc. Instn Elect. Engrs, 115, 528 (1964)

(3) Y. Tamura, H. Mori \& S. Iwamoto: "Relationship beween Voltage Instability and Multiple Load Flow Solutions in Power Systems", IEEE Trans. Power Apparalus Syst., PAS-102, 1115 (1983)

(4) P. Kessel \& H. Glavitsch, "Estimating the Voltage Stabil ity of a Power System", IEEE Trans. Power Delivery. PWRD-1. 346 (1986)

（5）長尾：「電力系統の受電端䨖圧の異常低下現象小，電学諭 $\mathrm{B}$, 95, 9 (昭 50-8)

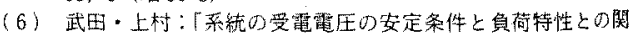
倸」，同上B、97，37(昭 52-9)

(7) S. Abe, Y. Fukunaga, A. Isono \& B. Kondo: "Power System Voltage Stability", IEEE Trons. Power Apparatus Syst., PAS-101, 3830 (1982)

(8) C. C. Liu \& K. T. Vu: "Analysis of Tap-changer Dynamics and Construction of Voltage Stability Regions, IEEE Trans. Circuits Syst.

(9) M. Brucoli, F. Rossi, F. Torelli \& M. Trovato: "A Gener alized Approach to the Analysis of Voltage Stability in Electric Power Systems", Electric Power Syst. Res. 9. 49 (1985)

(10) L. Zaragocin, H. Yan, R. O'Connell, F. Mercede \& R. Fischl: "A Review of Methods for Predicting Voltage Collapse of Power Systems", 1986 North American Power Symposium, Cornell Univ., p. 11 (1986) 
(11) V. A. Venikov, V. A. Stropev, V. I. Idelchick \& V. I. Tarasov: "Estimation of Electrical Power System Steady State Stability", IEEE Trans. Power Apparatus Syst., PAS -94, 1034 (1975)

(12) R. J. Thomas: "Analytical Methods for Analysis. Assessment and Control of Voltage Instabilities", IEEE PES Summer Meeting (1987)

(13) R. E. O'Mally Jr: Introduction to Singular Purterbations (1974) Academic Press, New York

（14）長尾·内田：「発電機特性上負荷特性を考虑した潮流計算法」, 電中研報告, No. 180008 （昭 55)

(15) G.W. Stagg \& A. H. El-Abiad: Computer Methods in Power System Analysis, p.369 (1968) McGraw-Hill

(16) C. J. Tavora \& O. J. M. Smith: "Stability Analysis of Power Systems", IEEE Trans. Power Apparatus Syst., PAS-91, 1138 (1972)

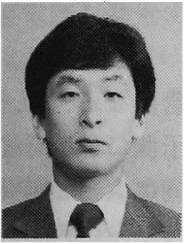

\section{餘利野 直 人（正員）}

昭和 33 年 1 月 24 日生。 58 年 3 月早稲田大学大学院修士課程修了。 同年 4 月富土電機製造 (株) 入社。59 年 4 月早稲田大学大学院理工学研究 科博士課程に進学。6 60 年 4 月早稲田大学理工学部助 手, 62 年 4 月広島大学工学部助手。工学博士。電力 系統安定度および電力系統の経済運用に関する研究に 従事。1985 年 George Montefiore 受賞。IEEE 会員。

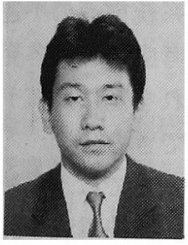

\section{增 田吉 彦 (准員)}

昭和 40 年 5 月 11 日生。平成 2 年 3 月広島大学大学院修士課程 (シス テム工学専攻)修了。同年四国電力 (株) 入社。

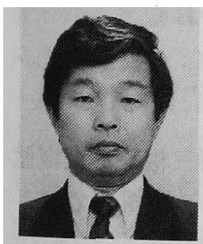

佐々木 博 司（正員）

昭和 16 年 3 月 10 日生。 43 年 3 月早稲田大学大学院理工学研究科博 士課程 (電気工学専攻) 修了。同年 4 月広島大学工学部電気工学科講 師, 55 年 10 月第二類 (電気系) 助教授, 平成元年 11 月同教授 (電力工学教育科目担当), 現在に至る。主 として, 電力系統の過渡安定度, 状態推定, 最適潮流 計算法，エキスパートシステムの応用に関する研究に
従事。工学博士。IEEE，CIGRE，日本太陽エネルギ 一学会, 情報処理学会, エネルギー・資源研究会会員。

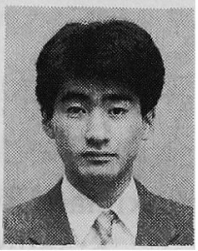

\section{西 重 和 弘（正員）}

昭和 40 年 2 月 21 日生。 62 年 3 月 三重大学工学部電子工学科卒業。平 成元年 3 月広島大学工学研究科シス テム工学専攻修士課程修了。同年 4 月住友電気工業(株)入社。現在, 同社光通信システム 事業部に勤務。主として，光 LAN システムの設計に 従事。

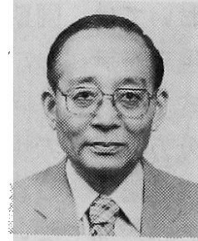

田 村 康 男 (正員)

昭和 6 年 9 月 21 日生。 28 年 3 月 早稲田大学理工学部電気工学科卒 業。33 年同大学大学院博士課程修 了。30 年同大学理工学部助手。 44 年教授。主として電力システム工学の研究・教育に従 事。工学博士。 59 年電気学会東京支部長, $62 \sim 64$ 年 副会長。6 60 年電気学会電力賞受賞。計測制御学会, IEEE，CIGRE 会員。

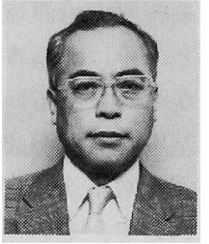

$$
\text { 北川 稔 (正員) }
$$

昭和 12 年 1 月 6 日生。 30 年宇部 工業高校電気科卒業。同年中国電力 (株) 入社。 40 年より同社技術研究 所にて電力工学全般の研究開発に従 事。現在, 電気担当次長。工学博士。

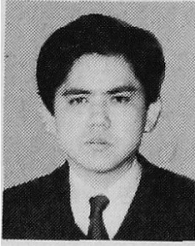

\section{大 下哲 (非会員)}

昭和 33 年 8 月 9 日生。 59 年東京 工業大学大学院工学研究科修士課程 修了。同年中国電力 (株) 入社。62 年より同社技術研究所にて電力系統 保護・解析に関する研究業務に従事。電子情報通信学 会会員。 